\title{
PENGARUH PELAKSANAAN TEHNIK DEEP BREATING (NAFAS DALAM) TERHADAP PENURUNAN TEKANAN DARAH PADA LANSIA DENGAN HIPERTENSI DI POSYANDU BALADASEPAKAT DI WILAYAH KERJA PUSKESMAS TANJUNG PAKU KOTA SOLOK
}

\author{
NETTY HERAWATI \\ Akademi Keperawatan YPTK Solok
}

\begin{abstract}
Hypertension is the main cause of stroke which brings high mortality. The cause of hypertension consists of genetic and environmental factors, Along with the changing lifestyle of hypertension cases continues to increase. According to the WHO International Hypertension Society there are currently 600 million sufferers worldwide, and 3 million of them die each year. Based on the results of interviews with hypertension patients who visited the Tanjung Paku Puskesmas among the elderly, said if their high blood pressure always went to the Puskesmas and took hypertension medication, but still rarely did non-pharmacological treatment, so far it was more likely if there were complaints such as headaches, shoulders feels heavy then go straight to the health center. This type of research in this study is a pre-experimental design "One Pre-Test-Post Test Design" in this study the group of subjects was measured blood pressure before deep breathing techniques (pre-test), then carried out deep breating (intervention) and measured again pressure blood after deep breating technique (post test). From the statistical test there was a significant difference between systole blood pressure before and after the deep breathing technique with a $p$ value of 0,000 > 0.05. It is expected that health workers can provide more optimal information, especially for patients with hypertension both mild, mild, moderate and severe to help hypertension sufferers in lowering blood pressure in a nonpharmacological manner.
\end{abstract}

Keywords: Deep breathing technique, Decreased blood pressure

\section{A. Pendahuluan}

Peningkatan penyakit tidak menular (PTM) dikarenakan salah satunya karena gaya hidup yang tidak sehat. Beberapa penyakit tidak menular yang biasa terjadi dimasyarakat seperti penyakit jantung koroner, diabetes mellitus, stroke, hipertensi. Hipertensi merupakan keadaan peningkatan tekanan darah yang memberikan gejala yang akan berlanjut keorgan lain seperti mengalami stroke, penyakit jantung koroner. Hipertensi menjadi penyebab utama stroke yang membawa kematian yang tinggi. Penyebab hipertensi terdiri dari faktor genetik dan lingkungan, sedangkan untuk faktor keturunan dapat dilihat dari faktor riwayat keluarga dan penyakit kardiovaskuler yang dapat berupa sensitifitas terhadap natrium, kepekaan terhadap stress, konsumsi garam berlebihan, sedangkan penyebab hipertensi dari lingkungan seperti stress psikis dan obesitas. Menurut WHO Internasional Society Hipertension saat ini terdapat 600 juta penderita diseluruh dunia, dan 3 juta diantaranya meninggal tiap tahun dan 7 dari setiap 10 penderita tersebut tidak mendapat pengobatan secara adekuat. (Mulyati, 2013), sementara di Indonesia penyakit hipertensi semangkin meningkat, namun sayang jumlah penderita dari jumlah total hanya baru 50\% yang terdeteksi, sementara penderita tersebut hanya setengahnya yang berobat secara teratur (Suraoka, 2012).

Berdasarkan survey yang dilakukan terhadap penderita hipertensi di Wilayah Puskesmas Tanjung Paku Kota Solok, dimana dari empat Puskesmas yang ada jumlah penderita hipertensi terbanyak di Kampung Jawa, dan berdasarkan hasil wawancara 
terhadap penderita hipertensi yang berkunjung ke Puskesmas Tanjung Paku diantarnya lansia, mengatakan jika tekanan darahnya tinggi selalu pergi berobat ke Puskesmas dan minum obat hipertensi, namun masih jarang penderita melakukan pengobatan secara nonfarmakologi, selama ini lebih cenderung jika terasa keluhan seperti sakit kepala, pundak terasa berat maka langsung berobat ke Puskesmas. Menurut Purnomo, pengobatan hipertensi dapat dilakukan dengan dua cara pengobatan farmakologi dan nonfarmakologi. Pengobatan nonfarmakologi dapat dilakukan dengan cara penurunan berat badan, olahraga, mengurangi asupan garam, tidak merokok, menghindari stress dan melakukan tehnik relaksasi seperti terapi musik, yoga atau meditasi, melakukan tehnik nafas dalam dan tehnik relaksasi lainnya.

\section{B. Metodologi Penelitian}

Jenis penelitian dalam penelitian ini adalah pra eksperimen dengan desain "One Pre Test - Post Test Design" pada penelitian ini kelompok subjek di ukur tekanan darah sebelum dilakukan tehnik deep breathing (pre-test), kemudian dilakukan deep breating (intervensi) dan diukur kembali tekanan darah setelah dilakukan tehnik deep breating (post test) untuk mengetahui perubahan pada tekanan darah setelah diberikan.

Desain Penelitian

\begin{tabular}{|lccc|}
\hline $\begin{array}{l}\text { Subjek } \\
\text { Test }\end{array}$ & Pre test & Perlakuan & Post \\
\hline $\begin{array}{c}\text { K } \\
\text { Time 2 }\end{array}$ & ( 0 ) Time 1 & I & $(01)$ \\
\hline
\end{tabular}

\section{Hasil dan Pembahasan}

1. Hasil

a. Karakterisitik Umur Responden

Tabel 1

Distribusi Frekuensi Responden Berdasarkan Kelompok Umur di Posyandu Balada Sepakat Wilayah Kerja Puskesmas Tanjung Paku Kota Solok

\begin{tabular}{|c|c|c|c|}
\hline No & Kelompok Umur & $\mathbf{f}$ & $\%$ \\
\hline 1 & Middle Age (45 - 59 tahun) & - & $0 \%$ \\
\hline 2 & Elderly (60 - 74 tahun) & 10 & $100 \%$ \\
\hline 3 & Old (75 - 90 tahun) & - & - \\
\hline 4 & Very Old ( $>90$ tahun) & - & - \\
\hline & Jumlah & 10 & 100 \\
\hline
\end{tabular}

Berdasarkan tabel diatas diketahui bahwa seluruhnya (100\%) responden berada pada kelompok usia Elderly (60-74 tahun).

\section{b. Jenis Kelamin}

Tabel 2

Distribusi Frekuensi Responden Berdasarkan Jenis Kelamin di Posyandu Balada Sepakat Wilayah Kerja Puskesmas Tanjung Paku Kota Solok

\begin{tabular}{|c|c|c|c|c|c|}
\hline & \multicolumn{5}{|c|}{ Solok } \\
\hline & No & Kelompok Jenis Kelamin & $\mathbf{F}$ & $\%$ & \\
\hline & 1 & Laki-Laki & 1 & $10 \%$ & \\
\hline & 2 & Perempuan & 9 & $90 \%$ & \\
\hline & \multicolumn{2}{|r|}{ Jumlah } & 10 & & 100 \\
\hline 20 & \multicolumn{4}{|c|}{ Lembaga Penelitian dan Penerbitan Hasil Penelitian Ensiklopedia } & $\begin{array}{l}\text { EISSN 2657-0289 } \\
\text { PISSN } 2657-0297\end{array}$ \\
\hline
\end{tabular}


Berdasarkan tabel diatas diketahui bahwa sebagian besar $(90,0 \%)$ responden berjenis kelamin perempuan.

\section{c. Pendidikan}

Tabel 3

Distribusi Frekuensi Responden Berdasarkan Tingkat Pendidikan di Posyandu Balada Sepakat di Wilayah Kerja Puskesmas

Tanjung Paku Kota Solok

\begin{tabular}{|l|l|l|l|}
\hline No & Pendidikan & F & \% \\
\hline 1 & Pendidikan dasar (SD- & 8 & $80,0 \%$ \\
2 & SMP) & 2 & $20,0 \%-$ \\
3 & Menengah (SMA) & - & \\
& Tinggi (PT) & & \\
\hline \multicolumn{2}{|c|}{ Jumlah } & $\mathbf{1 0}$ & \\
\hline
\end{tabular}

Berdasarkan tabel diatas diketahui bahwa sebagian besar $(80,0 \%)$ responden berpendidikan dasar (SD - SMP).

\section{C.Hasil Penelitian}

a. Hasil Univariat

Tekanan Darah Sebelum dilakukan Tehnik Deep Breathing (Nafas Dalam)

Distribusi Frekuensi Responden Berdasarkan Tekanan Darah Sebelum dilakukan

Tehnik Deep Breathing (Nafas Dalam) di Posyandu Balada Sepakat di Wilayah Kerja Tanjung Paku Kota Solok

\begin{tabular}{|c|c|}
\hline No Responden & $\begin{array}{c}\text { Hasil Ukur Tekanan Darah Sebelum dilakukan } \\
\text { Intervensi (Systole) }\end{array}$ \\
\hline 1 & 140 \\
2 & 140 \\
3 & 144 \\
4 & 144 \\
5 & 146 \\
6 & 146 \\
7 & 148 \\
8 & 150 \\
9 & 150 \\
10 & 150 \\
\hline Nilai Max & $\mathbf{1 5 0}$ \\
\hline Nilai Min & $\mathbf{1 4 0}$ \\
\hline Mean & $\mathbf{1 4 5}$ \\
\hline Standar & $\mathbf{3 , 8}$ \\
\hline deviasi & \\
\hline
\end{tabular}

Berdasarkan tabel diatas nilai mean pada tekanan darah responden sebelum dilakukan tehnik deep breathing (nafas dalam) pada tekanan darah systole yaitu $145 \mathrm{mmhg}$ 
Tekanan Darah Sesudah dilakukan Tehnik Deep Breathing (Nafas Dalam) Distribusi Frekuensi Responden Berdasarkan Tekanan Darah Sesudah dilakukan Tehnik Deep Breathing (Nafas Dalam) di Posyandu Balada Sepakat di Wilayah Kerja Tanjung Paku Kota Solok

\begin{tabular}{|c|c|}
\hline No Responden & $\begin{array}{c}\text { Hasil Ukur Tekanan Darah Sebelum dilakukan } \\
\text { Intervensi (Systole) }\end{array}$ \\
\hline 1 & 135 \\
2 & 138 \\
3 & 140 \\
4 & 140 \\
5 & 140 \\
6 & 140 \\
7 & 143 \\
8 & 144 \\
9 & 144 \\
10 & 146 \\
\hline Nilai Max & $\mathbf{1 4 6}$ \\
\hline Nilai Min & $\mathbf{1 3 5}$ \\
\hline Mean & $\mathbf{1 4 1}$ \\
\hline Standar deviasi & $\mathbf{3 , 2}$ \\
\hline
\end{tabular}

Berdasarkan tabel diatas nilai mean pada tekanan darah responden sesudah dilakukan tehnik deep breathing (nafas dalam) pada tekanan darah systole yaitu $141 \mathrm{mmhg}$

\section{b. Hasil Bivariat}

Pengaruh Pelaksanaan Tehnik Deep Breathing (Nafas Dalam) Terhadap Penurunan Tekanan darah Systole pada Penderita Hipertensi

Perbedaan Tekanan Darah Systole Sebelum dan Sesudah dilakukan Tehnik Deep Breathing (Nafas Dalam) di Posyandu Balada Sepakat di Wilayah Kerja Tanjung Paku Kota Solok

\begin{tabular}{|c|c|c|}
\hline No & $\begin{array}{c}\text { Hasil Ukur Tekanan Darah } \\
\text { Sebelum dilakukan } \\
\text { Intervensi (Systole) }\end{array}$ & $\begin{array}{c}\text { Hasil Ukur Tekanan Darah } \\
\text { Sesudah dilakukan } \\
\text { Intervensi (Systole) }\end{array}$ \\
\hline 1 & 140 & 135 \\
2 & 140 & 138 \\
3 & 144 & 140 \\
4 & 144 & 140 \\
5 & 146 & 140 \\
6 & 146 & 140 \\
7 & 148 & 143 \\
8 & 150 & 144 \\
9 & 150 & 144 \\
10 & 150 & 146 \\
\hline Nilai Max & $\mathbf{1 5 0}$ & $\mathbf{1 4 6}$ \\
\hline Nilai Min & $\mathbf{1 4 0}$ & $\mathbf{1 3 5}$ \\
\hline Mean & $\mathbf{1 4 5}$ & $\mathbf{1 4 1}$ \\
\hline Standar deviasi & $\mathbf{3 , 8}$ & $\mathbf{3 , 2}$ \\
\hline
\end{tabular}




\section{$P$ value $=0,000$}

Berdasarkan tabel diatas diketahui nilai mean pada tekanan darah systole sebelum dilakukan tehnik deep breathing (nafas dalam) adalah $145 \mathrm{mmhg}$ dengan standar deviasi 3,8, sedangkan nilai mean tekanan darah sesudah dilakukan tehnik deep breathing (nafas dalam) adalah $141 \mathrm{mmhg}$ dengan standar deviasi 3,2. Terlihat adanya perbedaan antara tekanan darah systole sebelum dan sesudah dilakukan tehnik deep breathing (nafas dalam). Hasil uji statistic menunjukkan terdapatnya perbedaan signifikan anatar tekanan darah systole sebelum dan sesudah dilakukan tehnik deep breathing (nafas dalam) dengan $p$ value $=0,000$.

\section{Pembahasan}

a. Perbedaan Tekanan Darah Systole Sebelum dan Sesudah dilakukan Deep Breathing (Nafas dalam) di Posyandu Balada Sepakat Di Wilayah Kerja Puskesmas Tanjung Paku Kota Solok .

Dari uji statistik terdapat perbedaan signifikan antara tekanan darah systole sebelum dan sesudah dilakukan tehnik deep breathing (nafas dalam) dengan $p$ value $0,000>0,05$. Penelitian ini sejalan dengan penelitian yang dilakukan Yanti (2016) di Wilayah Kerja Puskesmas 1 Denpasar dengan hasil penelitian $p$ value 0,000 berarti terdapatnya perbedaan tekan darah sebelum dan sesudah dilakukan intervensi. Melakukan tehnik relaksasi akan sangat membantu dalam menurunkan tekanan darah, salah satu tehnik relaksasi yang paling efektif digunakan dalam menurunkan tekanan darah yaitu dengan tehnik nafas dalam (Deep breathing). Pemgaruh penurunan tekanan darah ini bisa berlangsung sekitar 25 jam setelah tehnik nafas dalam terakhir dilakukan. Tehnik nafas dalam dikatakan secara teratur dilakukan jika penderita melakukan tehnik nafas dalam sebanyak 3 kali dalam satu sesi relaksasi dan dilakukan sesring mungkin(dalam satu hari). Beberapa peneliti yang telah melakukan sebelumnya bahwa tehnik nafas dalam yang dilakukan dengan benar dan teratur dengan instensitas sesering mungkindalam sehari dapat menurunkan $60 \%$ lebih besar dibanding orang yang tidak melakukan tehnik nafas dalam. ( Sutanto, 2014 ).

Kenyataan yang ditemukan dilapangan dimana rata-rata tekanan darah systole responden mengalami penurunan, namunn pelaksanan tehnik deep breathing belum dilakukan secara terartur oleh responden.

\section{Penutup}

Berdasarkan hasil penelitian yang dilakukan terhadap 10 orang responden diketahui nilai mean pada tekanan darah systole sebelum dilakukan tehnik deep breathing (nafas dalam) adalah $145 \mathrm{mmhg}$ dengan standar deviasi 3,8, sedangkan nilai mean tekanan darah sesudah dilakukan tehnik deep breathing (nafas dalam) adalah 141 mmhg dengan standar deviasi 3,2. Hasil uji statistik terdapat perbedaan signifikan antara tekanan darah systole sebelum dan sesudah dilakukan tehnik deep breathing (nafas dalam) dengan $p$ value $0,000>0,05$. Diharapkan kepada petugas kesehatan untuk dapat memberikan informasi lebih optimal terutama kepada penderita hipertensi baik ringan, sedang maupun berat untuk membantu penderita hipertensi dalam menurunkan tekanan darah secara non farmakologi..

\section{Daftar Pustaka}

Alimul, Aziz H. 2011. Metode Penelitian Keperawatan dan Teknik Analisa Data. Jakarta: Salemba Medika 
Arikunto, S. 2012. Prosedur Penelitian: Suatu Pendekatan Praktek. Jakarta: Rhinneka Cipta

Bustan. 2010. Epidemiologi Penyakit Tidak Menular. Jakarta : PT Rineka Cipta. Heru Purnomo, 2013. Penyakit yang Mematikan, Yogyakarta. Buana Pustaka Myra Utami, 2014. Mengatasi Cara Mudah Mengatasi Hipertensi. Yogyakarta Notoatmodjo. S. 2012. Metodologi Penelitian Kesehatan. Jakarta. Rineka Cipta Nurul Wahdah, 2012. Manaklukan Hipertensi dan Diabetes, Yogyakarta : Multipress Suraoka. 2012. Penyakit degeratif. Yogyakarta. Nuha Medika Sutanto, 2010. Cekal Penyakit Modern. Yogyakarta : Andi Offset Utami, P, 2011. Solusi Sehat Mengatasi Hipertensi, Jakarta : Agromedia Pustaka Ulfah N, 2012. Stop Hipertensi, Yogyakarta. 